\title{
PERANCANGAN SISTEM PENCARIAN TITIK DAYA MAKSIMUM PANEL SURYA DENGAN ALGORITMA PERTURB AND OBSERVE MENGGUNAKAN KONVERTER ARUS SEARAH TIPE BOOST
}

\author{
Fiqih Anugerah Fariz*), Iwan Setiawan, dan Mochammad Facta \\ Departemen Teknik Elektro, Universitas Diponegoro \\ Jl. Prof. Sudharto, SH, Kampus UNDIP Tembalang, Semarang 50275, Indonesia \\ *)E-mail: fiqihanugerah@gmail.com
}

\begin{abstract}
Abstrak
Penggunaan energi surya sebagai sumber energi listrik memiliki beberapa kelemahan, seperti daya listrik yang dihasilkan oleh panel surya dipengaruhi oleh iradiasi sinar matahari, suhu lingkungan, dan sudut datang matahari. Hal ini menyebabkan daya yang dihasilkan akan mengalami fluktuasi. Maximum Power Point Tracking (MPPT) merupakan suatu metode untuk memaksimalkan daya keluaran yang dihasilkan oleh panel surya. Penelitian ini bertujuan untuk merancang sistem MPPT menggunakan rangkaian boost converter dengan algoritma Perturb and Observe. Pengujian sistem MPPT dilakukan dengan memvariasi nilai iradiasi dan beban, kemudian menganalisis daya keluaran panel surya tersebut, serta membandingkan daya keluaran sistem yang menggunakan MPPT dan tidak menggunakan MPPT terhadap perubahan beban. Sistem pencarian titik daya maksimum panel surya menggunakan rangkaian boost converter dengan algoritma Perturb and Observe telah berhasil direalisasikan. Daya maksimum yang dihasilkan sistem MPPT dengan variasi beban $39 \Omega, 50 \Omega$, dan $100 \Omega$ pada iradiasi $1092 \mathrm{~W} / \mathrm{m}^{2}$ dan suhu $29^{\circ} \mathrm{C}$ adalah $29,32 \mathrm{~W}$, sedangkan pada iradiasi $752 \mathrm{~W} / \mathrm{m}^{2}$ dan suhu $29^{\circ} \mathrm{C}$ adalah $24,56 \mathrm{~W}$. Sistem MPPT dapat mempertahankan nilai daya pada titik maksimalnya saat terjadi perubahan beban, sedangkan pada sistem yang tidak menggunakan MPPT nilai daya yang dihasilkan akan berubahubah sesuai dengan perubahan beban.
\end{abstract}

Kata kunci : Boost converter, MPPT, Panel surya, Perturb and Observe

\begin{abstract}
The use of solar energy as a source of electrical energy has several disadvantages. The electrical power produced by solar panels is affected by irradiation of sunlight, ambient temperature, and the angle of sunlight arrival. These factors are causing the resulting power fluctuated. Maximum Power Point Tracking (MPPT) is a technique to maximize the output of power generated by solar panel. This work aims to design an MPPT system using boost converter with Perturb and Observe algorithm. Several tests of MPPT system are carried out by varying the irradiation and load. Analysis is made for the output of power from the solar panel, and comparison the system with and without MPPT as the load changes. Searching system of the solar panel's maximum power point applying a boost converter with Perturb and Observe algorithm is succesfully realized. The maximum power generated by the system with MPPT with variation in load $39 \Omega$, $50 \Omega$, and $100 \Omega$ for irradiation $1092 \mathrm{~W} / \mathrm{m}^{2}$ and a temperature $29^{\circ} \mathrm{C}$ is $29.43 \mathrm{~W}$, while for irradiation $752 \mathrm{~W} / \mathrm{m}^{2}$ and a temperature $29^{\circ} \mathrm{C}$, the maximum power is $24.56 \mathrm{~W}$. The MPPT system is able to maintain the power value at its maximum point when the load changes, meanwhile for a system does not use MPPT, the values of the power generated change according to the load changes.
\end{abstract}

Keywords : Boost Converter, MPPT, Solar panel, Perturb and Observe

\section{Pendahuluan}

Energi surya merupakan salah satu energi terbarukan yang sedang dikembangkan di Indonesia. Energi surya dapat dikonversikan menjadi energi listrik dengan menggunakan alat yang disebut panel surya. Panel surya memiliki beberapa kelebihan, yaitu ramah lingkungan dan biaya operasional yang rendah. Penggunaan energi surya sebagai sumber energi listrik memiliki beberapa kelemahan, seperti daya listrik yang dihasilkan oleh panel surya dipengaruhi oleh iradiasi sinar matahari, suhu lingkungan, dan sudut datang matahari [1]. Hal ini menyebabkan daya yang dihasilkan akan mengalami fluktuasi atau tidak konstan.

Maximum Power Point Tracking (MPPT) merupakan suatu metode untuk memaksimalkan daya keluaran yang dihasilkan oleh panel surya. MPPT berfungsi untuk menjejak daya yang dihasilkan panel surya agar berada 
pada titik maksimum dengan kondisi iradiasi dan suhu lingkungan yang berubah [2]. Terdapat dua jenis MPPT yang dapat digunakan untuk memaksimalkan daya keluaran panel surya, yaitu MPPT statis dan dinamis. MPPT statis merupakan metode pencarian titik daya maksimum panel surya berdasarkan kurva karakteristik, sedangkan MPPT dinamis merupakan metode pencarian titik daya maksimum panel surya berdasarkan sudut datang sinar matahari terhadap panel surya [2]. MPPT statis terdiri dari dua bagian utama, yaitu algoritma MPPT dan konverter arus searah. Beberapa contoh algoritma MPPT yang sering digunakan untuk aplikasi panel surya adalah Perturb and Observe (P\&O), Incremental Conductance, dan Fuzzy Logic [3]. Konverter arus searah berfungsi untuk menaikkan atau menurunkan nilai tegangan yang dihasilkan oleh panel surya.

Penelitian [4] membahas tentang sistem MPPT metode Incremental Conductance menggunakan konverter arus searah tipe Buck-Boost yang mampu menghasilkan ratarata daya maksimum panel surya sebesar $4,43 \mathrm{~W}$ menggunakan panel surya $10 \mathrm{Wp}$ pada iradiasi $1000 \mathrm{~W} / \mathrm{m}^{2}$ dan suhu $29^{\circ} \mathrm{C}$, pada penelitian [5]-[7] dibahas mengenai sistem MPPT metode P\&O menggunakan konverter arus searah tipe Buck-Boost, Sepic, Cuk.

Berdasarkan penelitian-penelitian sebelumnya, maka pada penelitian ini dilakukan perancangan sistem MPPT menggunakan konverter arus searah tipe boost dengan algoritma Perturb and Observe. Konverter arus searah tipe boost berfungsi untuk menaikkan nilai tegangan keluaran dari panel surya yang kemudian akan dihubungkan dengan beban. Sistem MPPT bertujuan untuk memaksimalkan daya keluaran pada panel surya untuk menyuplai beban.

\section{Metode}

\subsection{Perancangan Modul Panel Surya}

Modul panel surya yang digunakan pada penelitian ini adalah modul panel surya tipe polycrystalline dengan daya puncak sebesar $50 \mathrm{Wp}$. Spesifikasi dari modul panel surya yang digunakan dapat dilihat pada Tabel 1.

Tabel 1. Spesifikasi modul panel surya $50 \mathrm{Wp}$

\begin{tabular}{cc}
\hline Spesifikasi & Nilai \\
\hline Daya Maksimum (Pmaks) & $50 \mathrm{~W}$ \\
Tegangan Hubung Buka (VOC) & $22,2 \mathrm{~V}$ \\
Arus Hubung Singkat (ISC) & $2,90 \mathrm{~A}$ \\
Tegangan operasi optimal (Vmp) & $18 \mathrm{~V}$ \\
Arus operasi optimal (Imp) & $2,87 \mathrm{~A}$
\end{tabular}

\subsection{Perancangan Rangkaian Daya}

Rangkaian daya yang digunakan pada penelitian ini adalah konverter arus searah topologi boost converter. Boost converter digunakan untuk menaikkan nilai tegangan panel surya dengan polaritas tegangan keluarannya sama dengan polaritas tegangan masukan. Spesifikasi rangkaian boost converter dapat dilihat pada Tabel 2.

Tabel 2. Spesifikasi rangkaian boost converter

\begin{tabular}{cc}
\hline Spesifikasi & Nilai \\
\hline Tegangan Masukan & $0 \mathrm{~V}-22,2 \mathrm{~V}$ \\
Tegangan Keluaran & $50 \mathrm{~V}$ \\
Arus Maksimum & $3 \mathrm{~A}$ \\
Duty Cycle (D) & $10 \%-70 \%$ \\
Frekuensi Switching (fs) & $20 \mathrm{kHz}$ \\
\hline
\end{tabular}

Terdapat 5 komponen penyusun rangkaian boost converter, yaitu induktor, kapasitor, dioda, Metal Oxide Semiconductor Field Effect Transistor (MOSFET), dan resistor sebagai beban. Komponen penyusun boost converter yang digunakan pada penelitian ini dapat dilihat pada Tabel 3.

Tabel 3. Komponen penyusun boost converter

\begin{tabular}{cc}
\hline Komponen & Tipe/Nilai \\
\hline MOSFET & IRFP460 \\
Dioda & MUR1560 \\
Induktor & $480 \mu \mathrm{H}$ \\
Kapasitor & $220 \mu \mathrm{F} / 160 \mathrm{~V}$ \\
Resistor & $39 \Omega, 50 \Omega$, dan $100 \Omega$ \\
\hline
\end{tabular}

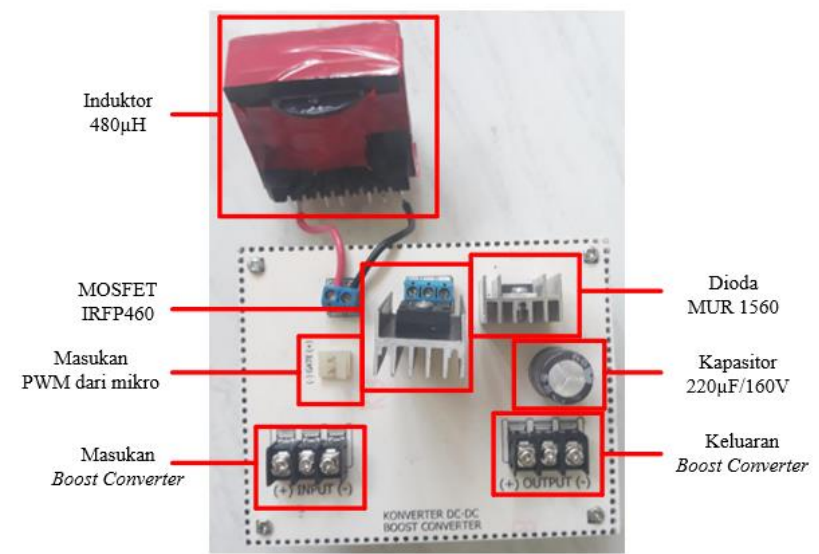

Gambar 1. Realisasi rangkaian boost converter 


\subsection{Perancangan Rangkaian Kontrol}

Perancangan rangkaian kontrol pada penelitian ini dibagi menjadi 3 bagian yaitu, perancangan rangkaian pembangkit PWM yang menggunakan Arduino Nano, perancangan sensor arus, dan perancangan sensor tegangan. Berikut merupakan penjelasan tiap bagian perancangan rangkaian kontrol pada penelitian ini.

\subsubsection{Sistem Minimum Arduino Nano}

Arduino Nano digunakan sebagai rangkaian kontrol pada penelitian ini. Arduino Nano berfungsi untuk menerima data hasil pembacaan tegangan dan arus dari boost converter, pembacaan data tegangan dan arus tersebut kemudian diolah oleh mikrokontroller untuk mengoperasikan algoritma MPPT. Arduino Nano diprogram untuk bekerja pada frekuensi sebesar $20 \mathrm{kHz}$. Pin 9 (Timer1) pada Arduino Nano digunakan sebagai pin keluaran PWM.

\subsubsection{Sensor Arus}

Sensor arus yang digunakan pada penelitian ini adalah ACS712-05B. Pemilihan sensor arus ACS712-05B pada penelitian ini mempertimbangkan nilai arus maksimum yang dapat melewati sensor tersebut yaitu sebesar 5A. Hal ini sudah cukup untuk mengukur arus keluaran panel surya yang memiliki nilai maksimal arus 2,97 A. Sensor arus ACS712-05B sudah dilengkapi dengan IC OpAmp atau penguat sinyal yang dapat digunakan untuk meningkatkan sensitivitas sensor [8]. Pengaturan OpAmp dapat dilakukan dengan mengatur offset dan gain melalui dua buah potensiometer. Pada penelitian ini, potensiometer offset dan gain diatur sedemikian rupa sehingga pada saat arus aktual yang mengalir melewati sensor sebesar 3 A, tegangan keluaran sensor sebesar $5 \mathrm{~V}$. Pengaturan nilai tersebut disesuaikan dengan batas arus keluaran maksimum panel surya yaitu sebesar 2,97 A. Potensiometer offset diatur agar pada saat arus bernilai 0 , tegangan keluaran sensor sebesar $1 \mathrm{~V}$. Potensiometer gain diatur sedemikian rupa hingga nilai sensitivitasnya sebesar $1 \mathrm{~V} / \mathrm{A}$.

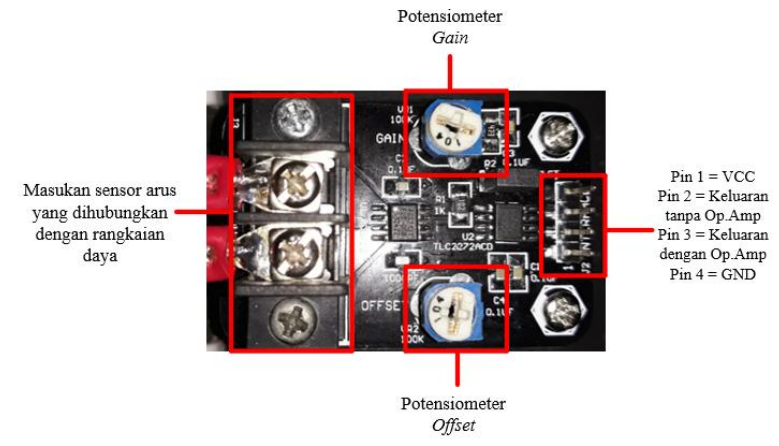

Gambar 2. Realisasi sensor arus

\subsubsection{Sensor Tegangan}

Sensor tegangan yang digunakan pada penelitian ini adalah rangkaian pembagi tegangan. Rangkaian pembagi tegangan dibuat menggunakan potensiometer jenis multi turn dengan nilai hambatan $500 \mathrm{k} \Omega$. Nilai hambatan potensiometer diatur sedemikian rupa sehingga pada saat nilai tegangan aktual sebesar $25 \mathrm{~V}$, maka tegangan yang terbaca oleh sensor tegangan sebesar $5 \mathrm{~V}$. Pengaturan nilai tersebut disesuaikan dengan batas tegangan keluaran maksimal panel surya yaitu sebesar $22,2 \mathrm{~V}$.

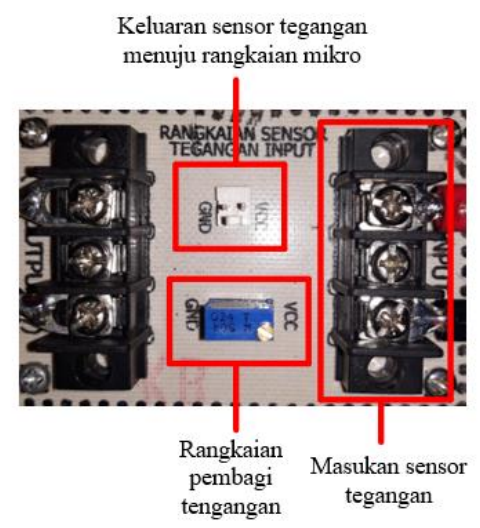

Gambar 3. Realisasi sensor tegangan

\subsection{Perancangan Rangkaian Driver}

Rangkaian driver MOSFET yang digunakan pada penelitian ini adalah TLP250. Pemilihan TLP250 sebagai rangkaian driver MOSFET pada penelitian ini dikarenakan TLP250 memiliki fungsi isolasi yang memisahkan ground rangkaian kontrol dengan rangkaian daya [9]. Selain itu, TLP250 juga dapat menguatkan sinyal PWM dengan nilai tegangan $5 \mathrm{~V}$ yang dibangkitkan oleh rangkaian kontrol menjadi sinyal PWM dengan nilai tegangan yang lebih tinggi (level tegangan $15 \mathrm{~V}$ ) sehingga dapat digunakan untuk memicu pensaklaran MOSFET IRFP460 yang membutuhkan tegangan VGS $\pm 20 \mathrm{~V}$.

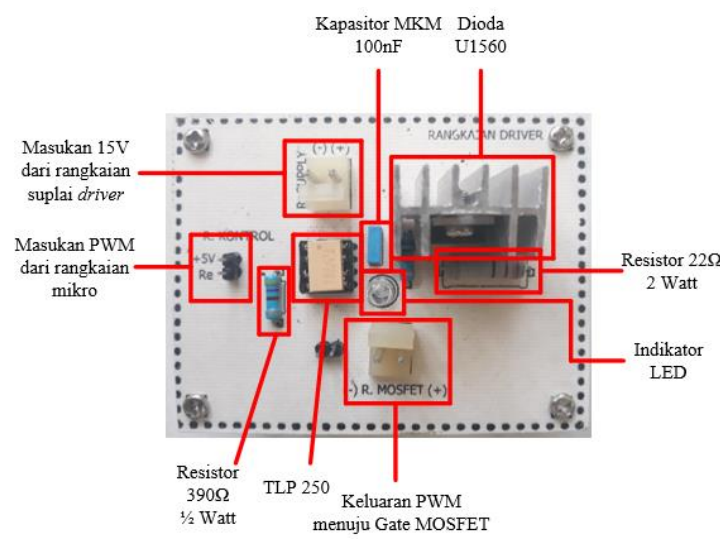

Gambar 4. Realisasi rangkaian driver MOSFET 


\subsection{Perancangan Algoritma MPPT}

Algoritma MPPT yang digunakan pada penelitian ini adalah Perturb \& Observe. Metode Perturb \& Observe merupakan metode untuk mencari titik daya maksimum panel surya yang bekerja berdasarkan nilai selisih daya dan selisih tegangan yang dihasilkan panel surya [10]. Diagram alir dari algoritma Perturb \& Observe ditunjukkan oleh Gambar 5.

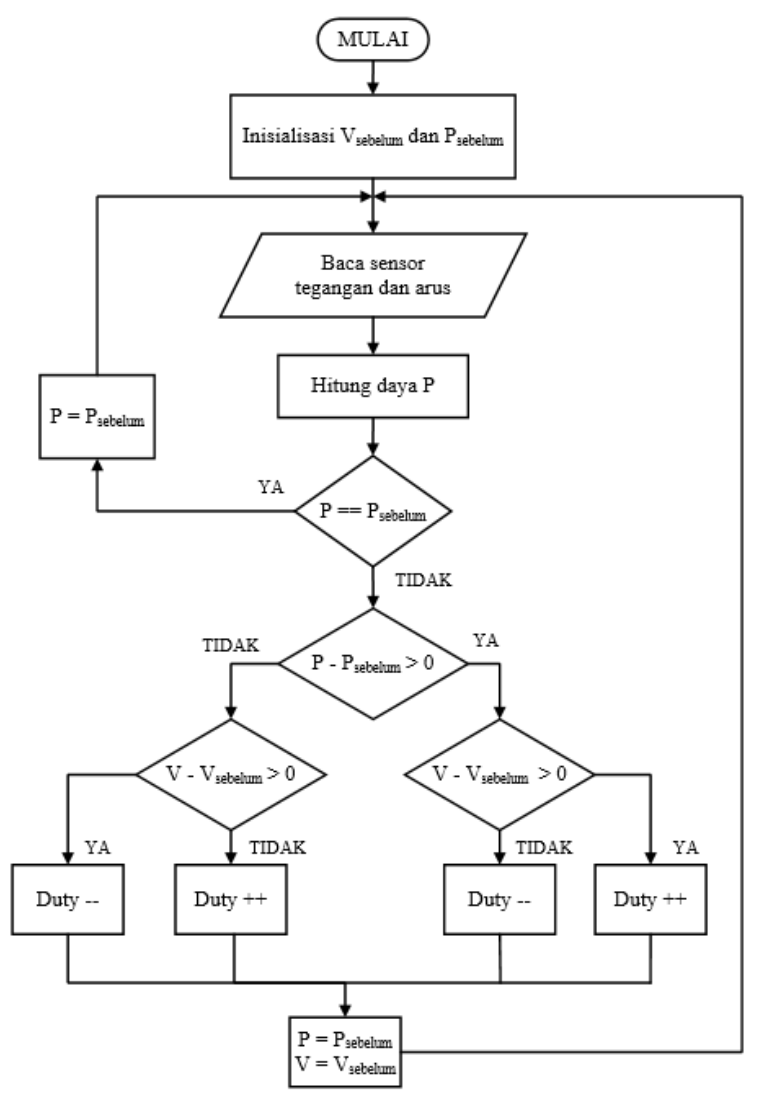

Gambar 5. Diagram alir metode Perturb and Observe

\section{Hasil dan Analisis}

\subsection{Pengujian Modul Panel Surya}

Pengujian panel surya bertujuan untuk mengetahui kurva karakteristik panel surya yang digunakan. Pengujian dilakukan dengan menghubungkan keluaran panel surya dengan rheostat. Pengaturan nilai rheostat akan mengubah nilai tegangan dan arus keluaran panel surya. Perubahan nilai tegangan dan arus keluaran panel surya akan membentuk kurva karakteristik panel surya tersebut. Pengujian karakteristik panel surya dilakukan pada iradiasi $1046 \mathrm{~W} / \mathrm{m}^{2}$ dan $742 \mathrm{~W} / \mathrm{m}^{2}$ dengan suhu $29^{\circ} \mathrm{C}$. Nilai daya didapatkan dengan mengalikan nilai arus dan tegangan keluaran panel surya.

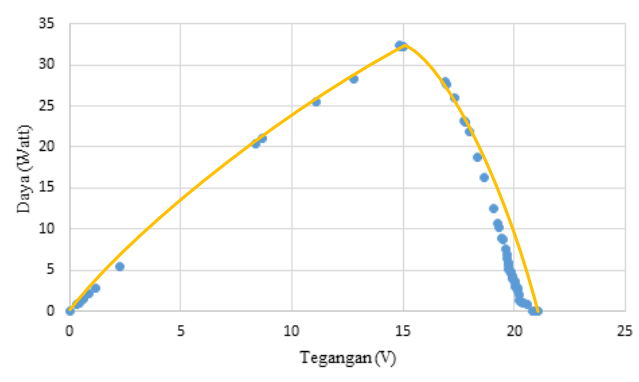

Gambar 6. Kurva daya dan tegangan iradiasi $1043 \mathrm{~W} / \mathrm{m}^{2}$ dan suhu $29^{\circ} \mathrm{C}$

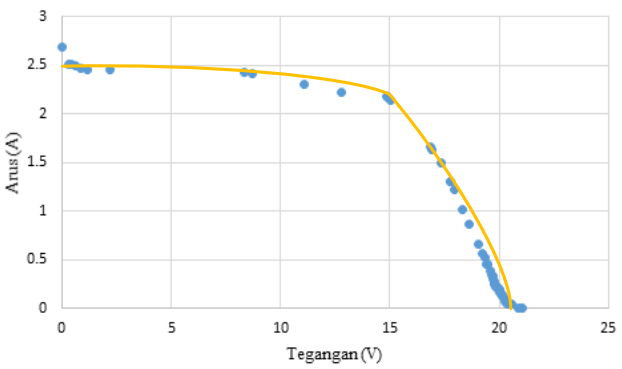

Gambar 7. Kurva arus dan tegangan iradiasi $1043 \mathrm{~W} / \mathrm{m}^{2}$ dan suhu $29^{\circ} \mathrm{C}$

Berdasarkan Gambar 6 dan Gambar 7, kurva karakteristik panel surya yang diuji sudah sesuai dengan gambar kurva karakteristik panel surya. Daya maksimum berada pada titik daya $32,32 \mathrm{~W}$ dengan tegangan $14,83 \mathrm{~V}$ pada saat iradiasi $1046 \mathrm{~W} / \mathrm{m}^{2}$ dan suhu $29^{\circ} \mathrm{C}$.

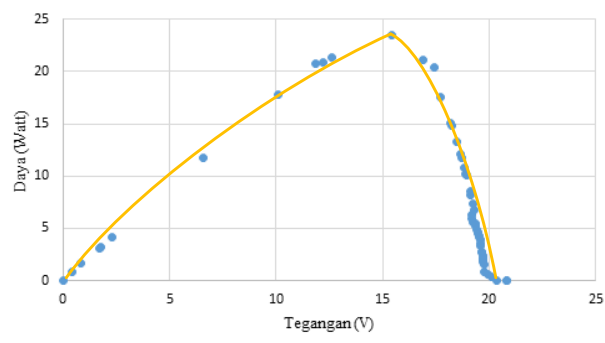

Gambar 8. Kurva daya dan tegangan iradiasi $742 \mathrm{~W} / \mathrm{m}^{2}$ dan suhu $29^{\circ} \mathrm{C}$

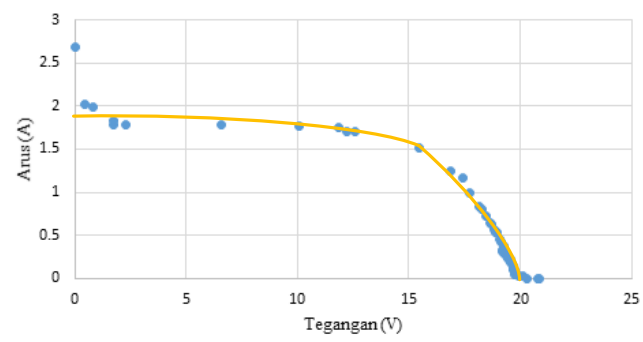

Gambar 9. Kuva arus dan tegangan iradiasi $742 \mathrm{~W} / \mathrm{m}^{2}$ dan suhu $29^{\circ} \mathrm{C}$ 
Berdasarkan Gambar 8 dan Gambar 9, kurva karakteristik panel surya yang diuji sudah sesuai dengan gambar kurva karakteristik panel surya. Daya maksimum berada pada titik daya $23,49 \mathrm{~W}$ dengan tegangan $15,46 \mathrm{~V}$ pada saat iradiasi $742 \mathrm{~W} / \mathrm{m}^{2}$ dan suhu $29^{\circ} \mathrm{C}$

\subsection{Pengujian Rangkaian Daya}

Pengujian rangkaian daya bertujuan untuk mengetahui kinerja konverter boost yang telah dirancang. Pengujian dilakukan dengan mengukur nilai tegangan masukan, arus masukan, tegangan keluaran, dan arus keluaran. Variasi beban dan duty cycle dilakukan untuk melihat perubahan nilai tegangan dan arus masukan maupun tegangan dan arus keluaran pada rangkaian boost converter.

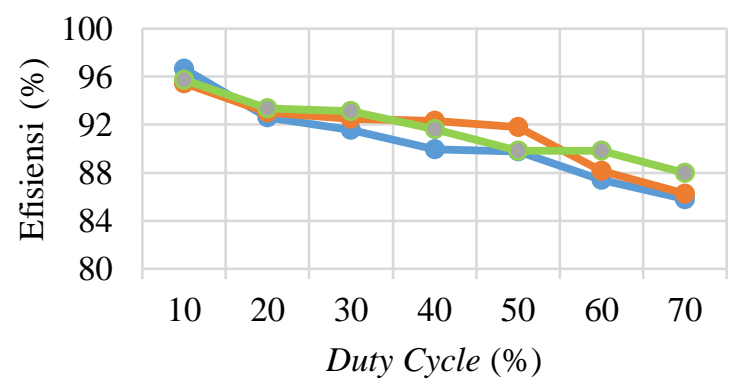

Beban $39 \Omega-$ Beban $50 \Omega-$ Beban $100 \Omega$

\section{Gambar 10. Efisiensi boost converter variasi duty cycle}

Berdasarkan grafik pada Gambar 10, didapatkan nilai ratarata efisiensi boost converter dengan beban $39 \Omega, 50 \Omega$, dan $100 \Omega$ secara berurutan adalah $90,53 \%, 91,36 \%$, 91,64\%. Nilai efisiensi boost converter tidak dapat mencapai $100 \%$ disebabkan karena adanya daya yang terbuang (daya disipasi) pada saat komponen penyusun rangkaian boost converter beroperasi. Nilai efisiensi akan mengalami penurunan dengan semakin besarnya nilai duty cycle. Penurunan nilai efisiensi tersebut disebabkan karena semakin besar nilai duty cycle, maka waktu pensaklaran MOSFET pada saat aktif akan semakin lama. Pada saat saklar MOSFET aktif, tegangan masukan boost converter akan mengalir menuju induktor sehingga induktor akan mengalami pengisian muatan. Semakin besar nilai duty cycle, maka pengisian muatan induktor akan semakin lama. Pengisian muatan induktor secara terus menerus sampai titik jenuhnya akan mengakibatkan jatuh tegangan pada sisi keluaran rangkaian boost converter. Hal ini mengakibatkan penurunan nilai efisiensi pada rangkaian boost converter.

\subsection{Pengujian Rangkaian Kontrol}

Pengujian rangkaian kontrol terdiri dari 3 bagian pengujian, yaitu pengujian rangkaian pembangkit PWM, pengujian sensor tegangan, dan pengujian sensor arus.
Pengujian tersebut bertujuan untuk mengetahui kinerja rangkaian kontrol dan ketelitian pembacaan sensor arus dan tegangan.

\subsubsection{Pengujian Rangkaian Pembangkit PWM}

Pengujian rangkaian pembangkit PWM bertujuan untuk mengamati dan menganalisis gelombang keluaran PWM yang dihasilkan Arduino Nano. Pengujian dilakukan dengan mengatur nilai duty cycle menggunakan potensiometer. Gambar 11 adalah gelombang keluaran PWM dengan nilai duty cycle $25 \%$ dan frekuensi $20 \mathrm{kHz}$.

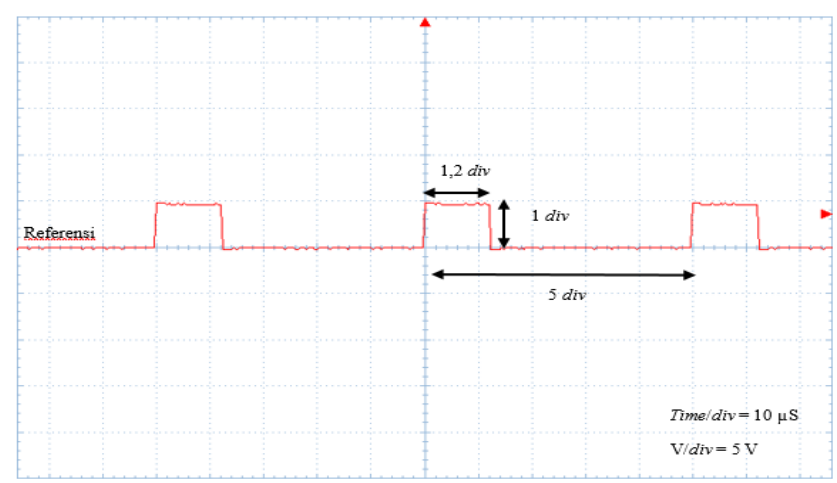

Gambar 11. Gelombang keluaran PWM duty cycle 25\%

\subsubsection{Pengujian Sensor Arus}

Pengujian sensor arus bertujuan untuk mengetahui tingkat ketelitian pembacaan sensor arus. Pengujian sensor arus dilakukan dengan menghubungkan sensor arus dengan sumber arus, kemudian nilai arus aktual akan dibandingkan dengan nilai arus hasil pembacaan sensor. Tabel 4 merupakan data hasil pengujian sensor arus.

Tabel 4. Hasil pengujian sensor arus

\begin{tabular}{ccc}
\hline Arus Aktual $(\mathrm{A})$ & Arus yang Dibaca Sensor $(\mathrm{A})$ & Error $(\%)$ \\
\hline 0,1 & 0,1 & 0 \\
0,2 & 0,2 & 0 \\
0,3 & 0,3 & 0 \\
0,4 & 0,39 & 2,5 \\
0,5 & 0,49 & 2 \\
0,6 & 0,6 & 0 \\
1 & 1 & 0 \\
1,5 & 1,5 & 0 \\
2 & 2 & 0 \\
2,5 & 2,5 & 0 \\
\hline
\end{tabular}

Berdasarkan data pada Tabel 4, didapatkan nilai error ratarata pembacaan sensor arus sebesar $0,45 \%$. Selisih nilai arus aktual dengan arus yang dibaca sensor disebabkan karena pembacaan sensor arus ACS712-05B dipengaruhi oleh medan magnet disekitar sensor.

\subsubsection{Pengujian Sensor Tegangan}

Pengujian sensor tegangan bertujuan untuk mengetahui tingkat ketelitian pembacaan sensor tegangan. Pengujian 
sensor tegangan dilakukan dengan menghubungkan sensor tegangan dengan sumber tegangan, kemudian nilai tegangan aktual akan dibandingkan dengan nilai tegangan hasil pembacaan sensor. Tabel 5 merupakan data hasil pengujian sensor tegangan.

Tabel 5. Hasil pengujian sensor tegangan

\begin{tabular}{ccc}
\hline $\begin{array}{c}\text { Tegangan } \\
\text { Aktual }(\mathrm{V})\end{array}$ & $\begin{array}{c}\text { Tegangan yang Dibaca Sensor } \\
(\mathrm{V})\end{array}$ & Error $(\%)$ \\
\hline 2 & 2 & 0 \\
4 & 3,98 & 0,5 \\
6 & 5,99 & 0,16 \\
8 & 7,98 & 0,25 \\
10 & 10 & 0 \\
12 & 12 & 0 \\
14 & 13,96 & 0,28 \\
16 & 15,97 & 0,18 \\
18 & 17,96 & 0,22 \\
20 & 19,97 & 0,15 \\
\hline
\end{tabular}

Berdasarkan data pada Tabel 5, didapatkan error rata-rata pembacaan sensor tegangan sebesar $0,176 \%$. Selisih nilai tegangan aktual dengan tegangan yang dibaca sensor disebabkan karena nilai toleransi resistor pada rangkaian pembagi tegangan dan pembulatan nilai konstanta dan nilai konversi nilai analog ke digital pada saat perhitungan.

\subsection{Pengujian Rangkaian Driver}

Pengujian rangkaian driver bertujuan untuk mengamati dan menganalisis gelombang keluaran PWM setelah mengalami penguatan oleh rangkaian driver. Gambar 12 merupakan gelombang keluaran PWM rangkaian driver.

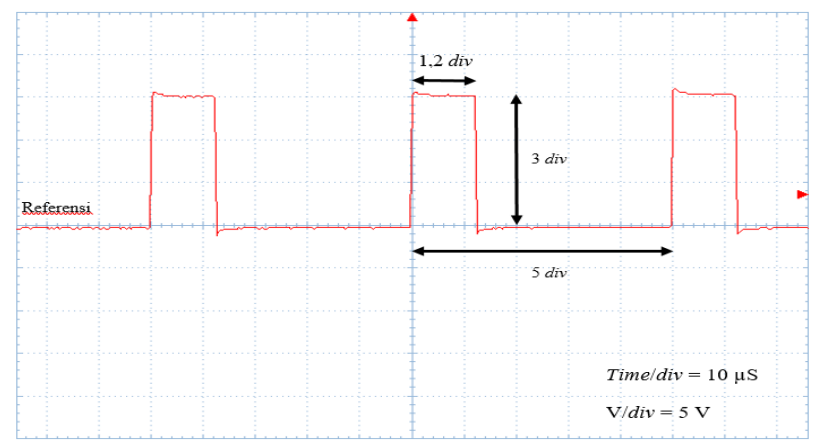

Gambar 12. Gelombang keluaran PWM TLP250 duty cycle $25 \%$

\subsection{Pengujian Algoritma MPPT}

Pengujian algoritma MPPT ini bertujuan untuk membuktikan bahwa algoritma yang digunakan sudah mampu menjejak titik daya maksimum panel surya. Pengujian MPPT dilakukan dengan variasi iradiasi dan variasi nilai beban. Variasi iradiasi yang dilakukan sebesar $1092 \mathrm{~W} / \mathrm{m}^{2}$ dan $752 \mathrm{~W} / \mathrm{m}^{2}$. Iradiasi didapatkan dari sinar matahari langsung. Beban yang digunakan pada pengujian MPPT adalah resistor dengan nilai $39 \Omega, 50 \Omega$, dan $100 \Omega$. Pada setiap variasi iradiasi, dilakukan switching beban yang akan mempengaruhi operasi MPPT. Pengujian dilakukan dengan membandingkan nilai daya keluaran sistem yang menggunakan MPPT dan tanpa menggunakan MPPT.

\subsubsection{Pengujian MPPT Iradiasi $1092 \mathrm{~W} / \mathrm{m}^{2}$ Suhu $29^{\circ} \mathrm{C}$}

Pengujian MPPT pada iradiasi $1092 \mathrm{~W} / \mathrm{m}^{2}$ dan suhu $29^{\circ} \mathrm{C}$ dilakukan dengan 3 variasi nilai beban, yaitu $39 \Omega, 50 \Omega$, dan $100 \Omega$. Gambar 13 merupakan grafik pengujian MPPT iradiasi $1092 \mathrm{~W} / \mathrm{m}^{2}$ dan suhu $29^{\circ} \mathrm{C}$.

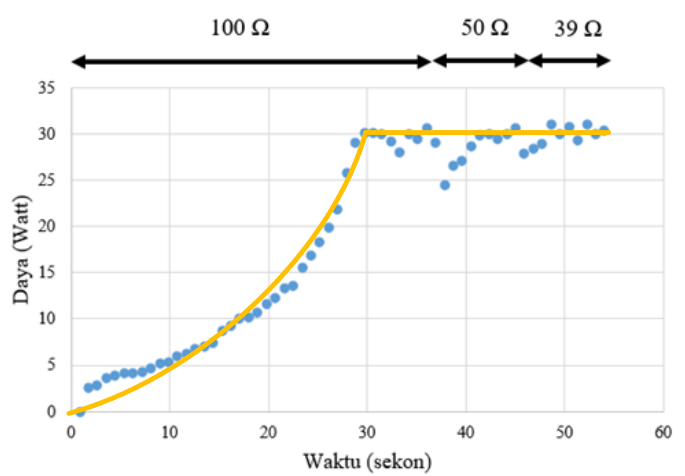

Gambar 13. Grafik MPPT iradiasi $1092 \mathrm{~W} / \mathrm{m}^{2}$ dan suhu $29^{\circ} \mathrm{C}$

Gambar 13 merupakan grafik pengujian MPPT iradiasi $1092 \mathrm{~W} / \mathrm{m}^{2}$ dan suhu $29^{\circ} \mathrm{C}$. Perubahan beban dilakukan sebanyak 3 variasi yaitu, $39 \Omega, 50 \Omega$, dan $100 \Omega$. Pengambilan data dilakukan dengan waktu sampling sebesar 0,9 detik. Daya maksimal rata-rata yang didapatkan dari pengujian tersebut adalah 29,32 W. Pada kondisi awal, sistem MPPT mulai menjejak titik daya maksimum panel surya. Setelah mencapai titik daya maksimumnya, sistem MPPT akan mempertahankan nilai daya pada titik maksimumnya meskipun terjadi perubahan beban.

\subsubsection{Pengujian MPPT Iradiasi $752 \mathrm{~W} / \mathrm{m}^{2}$ Suhu $29^{\circ} \mathrm{C}$}

Pengujian MPPT pada iradiasi $752 \mathrm{~W} / \mathrm{m}^{2}$ dan suhu $29^{\circ} \mathrm{C}$ dilakukan dengan 3 variasi nilai beban, yaitu $39 \Omega, 50 \Omega$, dan $100 \Omega$. Gambar 14 merupakan grafik pengujian MPPT iradiasi $752 \mathrm{~W} / \mathrm{m}^{2}$ dan suhu $29^{\circ} \mathrm{C}$.

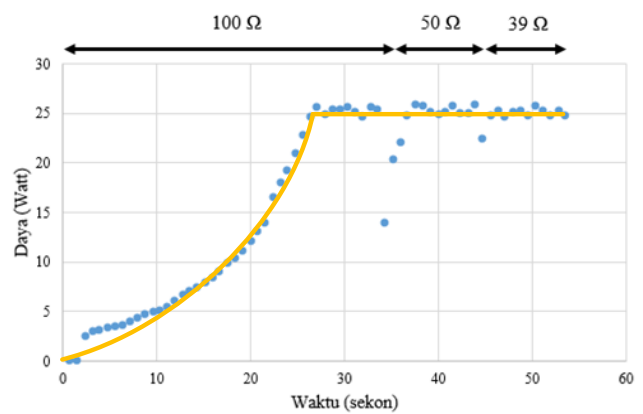

Gambar 14. Grafik MPPT iradiasi $752 \mathrm{~W} / \mathrm{m}^{2}$ dan suhu $29^{\circ} \mathrm{C}$ 
Gambar 14 merupakan grafik pengujian MPPT iradiasi 752 $\mathrm{W} / \mathrm{m}^{2}$ dan suhu $29^{\circ} \mathrm{C}$. Perubahan beban dilakukan sebanyak 3 variasi yaitu, $39 \Omega, 50 \Omega$, dan $100 \Omega$. Pengambilan data dilakukan dengan waktu sampling sebesar 0,8 detik. Daya maksimal rata-rata yang didapatkan dari pengujian tersebut adalah 24,56 W. Pada kondisi awal, sistem MPPT mulai menjejak titik daya maksimum panel surya. Setelah mencapai titik daya maksimumnya, sistem MPPT akan mempertahankan nilai daya pada titik maksimumnya meskipun terjadi perubahan beban.

\subsubsection{Perbandingan MPPT dan Tanpa MPPT Iradiasi $1092 \mathrm{~W} / \mathrm{m}^{2}$ Suhu $29^{\circ} \mathrm{C}$}

Perbandingan daya keluaran yang dihasilkan sistem yang menggunakan MPPT dan tanpa menggunakan MPPT diuji dengan memvariasi nilai beban. Beban yang digunakan pada pengujian ini adalah $39 \Omega, 50 \Omega$, dan $100 \Omega$. Pengambilan data MPPT dilakukan dengan waktu sampling 0,9 detik, sedangkan pengambilan data tanpa MPPT dilakukan dengan waktu sampling 0,7 detik. Gambar 15 merupakan grafik perbandingan daya keluaran sistem yang menggunakan MPPT dan tanpa MPPT pada iradiasi $1092 \mathrm{~W} / \mathrm{m}^{2}$ dan suhu $29^{\circ} \mathrm{C}$.

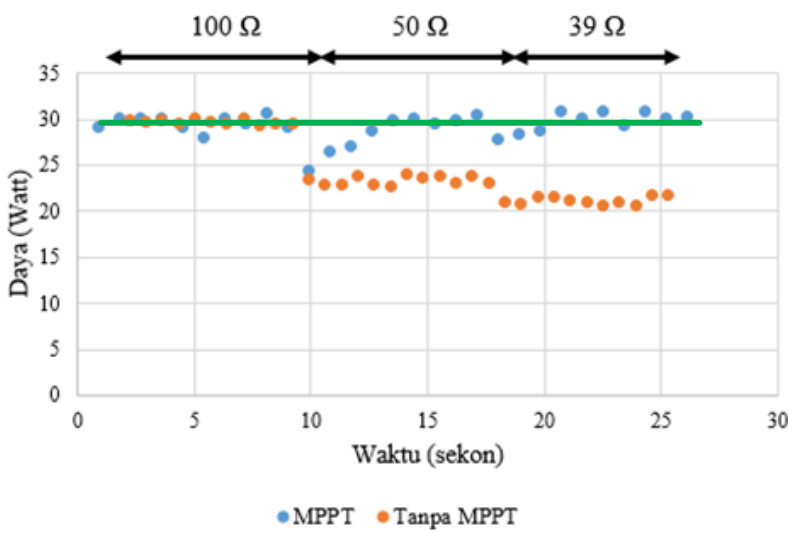

Gambar 15. Grafik perbandingan sistem MPPT dan tanpa MPPT iradiasi $1092 \mathrm{~W} / \mathrm{m}^{2}$ dan suhu $29^{\circ} \mathrm{C}$

Data pengujian MPPT dan tanpa MPPT yang ditampilkan pada Gambar 15 merupakan data dengan keadaan awal saat daya maksimum pada beban $100 \Omega$, kemudian dilakukan perubahan beban untuk menganalisis pengaruh perubahan beban terhadap daya yang dihasilkan sistem dengan MPPT dan tanpa MPPT. Berdasarkan Gambar 15 dapat dilihat bahwa daya yang dihasilkan sistem yang menggunakan MPPT relatif konstan pada saat terjadi perubahan beban. Daya maksimal rata-rata yang dihasilkan sistem yang menggunakan MPPT adalah 29,32 W. Pada sistem yang tidak menggunakan MPPT didapatkan nilai daya yang berubah-ubah pada saat terjadi perubahan beban. Daya rata-rata yang dihasilkan sistem yang tidak menggunakan MPPT pada beban $100 \Omega$ adalah $29,72 \mathrm{~W}, 23,34 \mathrm{~W}$ pada beban $50 \Omega$, dan $21,2 \mathrm{~W}$ pada beban $39 \Omega$. Sistem MPPT dapat mempertahankan nilai daya pada titik maksimalnya pada saat terjadi perubahan beban, sedangkan pada sistem yang tidak menggunakan MPPT nilai daya yang dihasilkan akan berubah-ubah sesuai dengan perubahan beban.

\subsubsection{Perbandingan MPPT dan Tanpa MPPT Iradiasi $752 \mathrm{~W} / \mathrm{m}^{2}$ Suhu $29^{\circ} \mathrm{C}$}

Perbandingan daya keluaran yang dihasilkan sistem yang menggunakan MPPT dan tanpa menggunakan MPPT diuji dengan memvariasi nilai beban. Beban yang digunakan pada pengujian ini adalah $39 \Omega, 50 \Omega$, dan $100 \Omega$. Pengambilan data MPPT dilakukan dengan waktu sampling 0,8 detik, sedangkan pengambilan data tanpa MPPT dilakukan dengan waktu sampling 0,8 detik. Gambar 16 merupakan grafik perbandingan daya keluaran sistem yang menggunakan MPPT dan tanpa MPPT pada iradiasi $752 \mathrm{~W} / \mathrm{m}^{2}$ dan suhu $29^{\circ} \mathrm{C}$.

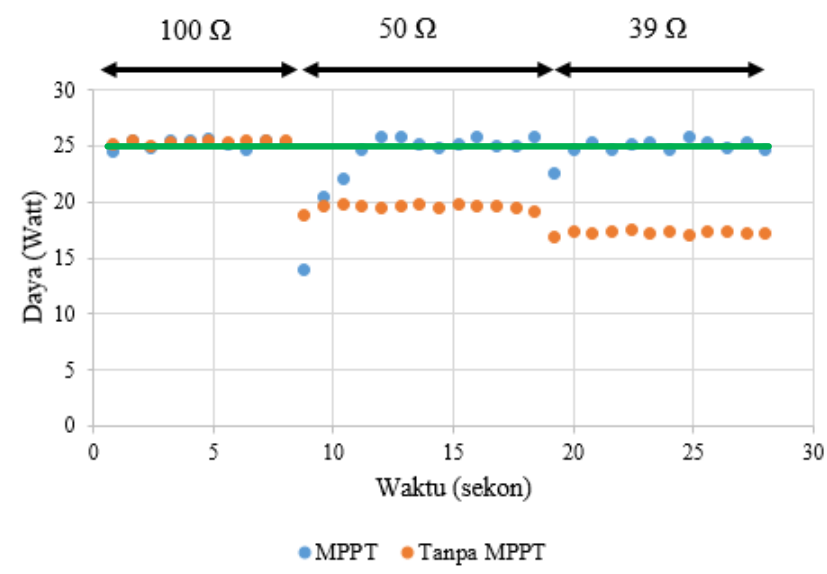

Gambar 16. Grafik perbandingan sistem MPPT dan tanpa MPPT iradiasi $752 \mathrm{~W} / \mathrm{m}^{2}$ dan suhu $29^{\circ} \mathrm{C}$

Data pengujian MPPT dan tanpa MPPT yang ditampilkan pada Gambar 16 merupakan data dengan keadaan awal saat daya maksimum pada beban $100 \Omega$, kemudian dilakukan perubahan beban untuk menganalisis pengaruh perubahan beban terhadap daya yang dihasilkan sistem dengan MPPT dan tanpa MPPT. Berdasarkan Gambar 16 dapat dilihat bahwa daya yang dihasilkan sistem yang menggunakan MPPT relatif konstan pada saat terjadi perubahan beban. Daya maksimal rata-rata yang dihasilkan sistem yang menggunakan MPPT adalah 24,56 W. Pada sistem yang tidak menggunakan MPPT didapatkan nilai daya yang berubah-ubah pada saat terjadi perubahan beban. Daya rata-rata yang dihasilkan sistem yang tidak menggunakan MPPT pada beban $100 \Omega$ adalah $25,34 \mathrm{~W}, 19,53 \mathrm{~W}$ pada beban $50 \Omega$, dan 17,24 W pada beban $39 \Omega$. Sistem MPPT dapat mempertahankan nilai daya pada titik maksimalnya pada saat terjadi perubahan beban, sedangkan pada sistem yang tidak menggunakan MPPT nilai daya yang dihasilkan akan berubah-ubah sesuai dengan perubahan beban. 


\section{Kesimpulan}

Berdasarkan hasil pengujian dan analisis pada penelitian ini dapat disimpulkan bahwa konverter arus searah tipe boost dengan sistem pencarian titik daya maksimum panel surya algoritma Perturb and Observe telah berhasil direalisasikan. Daya maksimum yang dihasilkan sistem menggunakan MPPT pada iradiasi $1092 \mathrm{~W} / \mathrm{m}^{2}$ dan suhu $29^{\circ} \mathrm{C}$ dengan variasi beban $39 \Omega, 50 \Omega$, dan $100 \Omega$ adalah 29,32 W. Daya maksimum yang dihasilkan sistem menggunakan MPPT pada iradiasi $752 \mathrm{~W} / \mathrm{m}^{2}$ dan suhu $29^{\circ} \mathrm{C}$ dengan variasi beban $39 \Omega, 50 \Omega$, dan $100 \Omega$ adalah 24,56 W. Sistem MPPT dapat mempertahankan nilai daya pada titik maksimalnya saat terjadi perubahan beban, sedangkan pada sistem yang tidak menggunakan MPPT nilai daya yang dihasilkan akan berubah-ubah sesuai dengan perubahan beban.

\section{Referensi}

[1] Handbook of Photovoltaic Science and Engineering, 1st ed., John Wiley \& Son Ltd, Chicester, England, 2003.

[2] D. S. Morales, "Maximum Power Point Tracking Algorithms for Photovoltaic Applications," Master's Thesis, Departement of Electrical Engineering, Aalto University, Finland, 2010.
[3] B. Bendib, H. Belmili, and F. Krim, "A survey of the most used MPPT methods: Conventional and advanced algorithms applied for photovoltaic systems," Renewable and Sustainable Energy Reviews, vol. 45. pp. 637-648, 2015

[4] N. Betantya, "Perancangan Maximum Power Point Tracking Panel Surya menggunakan Buck Boost Converter dengan Metode Incremental Conductance," Laporan Tugas Akhir, Departemen Teknik Elektro, Universitas Diponegoro, 2017.

[5] A. P. Haris, "Perancangan Maximum Power Point Tracking Panel Surya menggunakan Konverter BuckBoost dengan Algoritma Perturb and Observe," Laporan Tugas Akhir, Departemen Teknik Elektro, Universitas Diponegoro, 2017.

[6] R. Z. Ahmad. "Perancangan Konverter Arus Searah tipe SEPIC yang dioperasikan untuk Pencarian Titik Daya Maksimum Panel Surya berbasis Metode Perturbation and Observation (P\&O)," Laporan Tugas Akhir, Departemen Teknik Elektro, Universitas Diponegoro, Semarang, 2017.

[7] D. P. Arifna, "Perancangan Konverter Arus Searah tipe cuk yang dioperasikan untuk Pencarian Titik Daya Maksimum Panel Surya berbasis Perturb and Observe," Laporan Tugas Akhir, Departemen Teknik Elektro, Universitas Diponegoro, Semarang, 2017.

[8] DT-Sense Current Sensor, Innovative Electronics, Jakarta, 2012.

[9] TLP250, Toshiba Corporation, Japan, 2007.

[10] E. Trishan dan P. L. Chapman, "Comparison of Photovoltaic Array Maximum Power Point Tracking Techniques," IEEE Transactions on Energy Conversion, vol 22, no.2, hal 439-449, Juni, 2007. 